Вісник Дніпропетровського університету. Серія: геологія, географія. 24 (2), 2016, 11-17

Vìsnik Dnìpropetrovs'kogo unìversitetu. Serîa Geologîa, geographìâ

Dnipropetrovsk University Bulletin. Series: geology, geography. 24 (2), 2016, 11-17

Doi: $10.15421 / 111626$

http://geology-dnu.dp.ua

УДК $550.42+550.47$

\title{
Поглинання важких металів із грунту рослинністю зони техногенезу
}

\author{
Ю. Ю. Войтюк
}

Інститут геохімії, мінералогії та рудоутворення імені М. П. Семененка НАН України, Київ, Україна, e-mail:yuliasun86@mail.ru

Забруднення грунтів та трав'янистої рослинності спостерігали на моніторингових ділянках, що перебувають під впливом промислових підприсмств різного профілю: чорної металургії, хімічної промисловості та енергетики. Ділянки спостережень характеризуються середнім (помірно небезпечним) та високим (небезпечним) рівнем забруднення. Виділено техногенні геохімічні асоціації важких металів у грунтах. Установлено біогеохімічні особливості рослинного покриву зони техногенезу. Дано оцінку поглинання важких металів із грунту трав'янистою рослинністю техногенно забруднених територій. За величиною накопичення трав'янистою рослинністю важкі метали утворюють ряд: Мо > $\mathrm{Cu}>\mathrm{Sn}>\mathrm{Mn}>\mathrm{Co}>\mathrm{Ni}>\mathrm{Zn}>\mathrm{Pb}>\mathrm{Cr}>\mathrm{V}$. Проведені еколого-геохімічні дослідження показали, що в умовах сильного техногенного навантаження бар'єрний тип накопичення характерний для $\mathrm{Cu}, \mathrm{Zn}$ тa $\mathrm{Pb}$. Поглинання цих елементів віднесено до акумулятивного типу. Поглинання $\mathrm{Mn}, \mathrm{Cr}$ та V рослинами віднесено до індикаторного типу. Показано можливість використання результатів біогеохімічних досліджень рослинного покриву для виділення зон екологічного ризику та їх реабілітації.

Ключові слова: накопичення в рослинах, важкі метали, зона техногенезу

\section{The absorption of heavy metals by plants from soil zone technogenesis}

\author{
Iu. Iu. Voitiuk
}

M.P. Semenenko Institute of Geochemistry, Mineralogy and Ore Formation, National Academy of Sciences of Ukraine, Kyiv, Ukraine, e-mail: yuliasun86@mail.ru

Contamination of soils and plants (couch grass (Elytrigia repens)) were observed on monitoring sites, under the influence of the industrial enterprises of different profiles (steel (Mariupol, Alchevsk, Kamianske), chemicals (Shostka) and energy (Sumy)). The work is dedicated to determination regularities uptake of heavy metals from soil by plants technologically contaminated areas. The content of heavy metals in soils and plants were determined by atomic adsorption, and using ICP-MS analyzer ELENENT-2 (Germany). Ecological-geochemical assessment of soil contamination on the total index made by the method Yu. Sayeta. To characterize the biogenic migration of heavy metals and biochemical features of plants used method I. Avessalomovoyi. Areas of research are characterized by medium (moderately dangerous) and high (dangerous) pollution. Geochemical association of heavy metals in soil were identified. Biogeochemical characteristics of plants of technogenesis zones were established. Evaluation absorption of heavy metals from soil by plants technologically contaminated areas was given. Heavy metals accumulated in the plants form a series: $\mathrm{Mo}>\mathrm{Cu}>\mathrm{Sn}>\mathrm{Mn}>\mathrm{Co}>\mathrm{Ni}>\mathrm{Zn}>\mathrm{Pb}>\mathrm{Cr}>\mathrm{V}$. Couch grass growing on soils of different types, with different levels of poly- and monoelement contamination characterized by selective accumulation of chemical elements. Coefficient of biogeochemical activity type that describes the intensity of the absorption elements by plants is 5-10. The higher this value, the more pollution characterized area. Ash content is $12.5-\mathbf{1 4 . 5 \%}$. Establishing relationships between the concentration of metals in the soil and in plants conducted by the example of the city of Mariupol. Ecological and geochemical studies showed that under strong anthropogenic impact barrier type accumulation characteristic of $\mathrm{Cu}, \mathrm{Zn}$ and $\mathrm{Pb}$. The absorption of these elements attributed to the accumulator type. Absorption of $\mathrm{Mn}, \mathrm{Cr}$ and $\mathrm{V}$ plants classified as indicator type. The ability to use the results of biochemical studies plant cover to highlight areas of environmental risk and their rehabilitation was shown.

Keywords: accumulation in plants, heavy metals, technogenesis zone

Вступ. В останні десятиліття провідним процесом, що визначає формування еколого-геохімічного стану території, став техногенез. Інтенсивне промислове використання природних ресурсів викликало істотні зміни розподілу деяких хіміч- них елементів у таких депонувальних геохімічних середовищах як грунти та рослинність. Звертаючись до геохімічної екології рослин як розділу геохімічної екології та біогеохімії щодо взаємодії рослин із геохімічним середовищем, необхідно 
мати на увазі біологічну роль хімічних елементів у життєдіяльності рослин та еволюцію фізіологічних функцій макро- та мікроелементів (Ermakov, 2015).

Геохімічним особливостям поглинання важких металів із грунту рослинністю присвячені праці В. В. Ковальського, О. Л. Ковалевського, А. Кабати-Пендіас, В. В. Іванова, В. Б. Ільїна та ін. Особлива увага до такого роду досліджень викликана тим, що рослинний покрив є проміжною ланкою міграції важких металів із грунту в організм людини по трофічних ланцюгах. У наукових роботах сучасників (В. В. Срмакова, Н. М. Ладоніної, Т. М. Мінкіної, Г. В. Мотузової, Е. Я. Жовинського, А. І. Самчука, В. В. Доліна, Н. П. Грицан та ін.) все більше уваги приділяється з'ясуванню можливості використання рослин як біоіндикатирів забруднення важкими металами навколишнього середовища. Оцінка стійкості рослин до забруднення важкими металами дозволяє вирішити проблему нормування вмістів важких металів у грунтах та рослинах (Minkina, 2013). Тому дослідження переходу важких металів із грунту в рослини має велике наукове і практичне значення.

Мета роботи - встановлення закономірностей поглинання важких металів із грунту рослинністю техногенно забруднених територій.

Матеріал і методи досліджень. Для проведення еколого-геохімічних досліджень поглинання важких металів із грунту рослинністю було обрано ділянки, що зазнають техногенного навантаження від підприємств чорної металургії (м. Маріуполь, Алчевськ, Кам'янське), хімічної промисловості (м. Шостка) та енергетики (м. Суми). На цих ділянках накопичені високі концентрації важких металів у грунтах, що викликало зміни мікроелементного складу рослинного покриву та створило ризики еколого-геохімічного характеру (Karmazynenko, 2014; Kurajeva, 2016; Vojtjuk, 2015).

Об'єктами досліджень були грунти, а також трав'яниста рослинність ділянок спостережень. Відбір проб грунтових та рослинних зразків проводився 32011 р. по 2015 р. щорічно у другій декаді червня у період максимального розвитку вегетативної частини рослин. Відбір проб грунту проведено відповідно до вимог ГОСТ 17.4.4.0284. Опробування представницьких видів рослинності виконано паралельно з відбором грунтових проб. Вміст важких металів у грунтах та рослинах визначали атомно-адсорбційним методом на спектрометрі KAC-115, а також за допомогою ICP-MS аналізатора ELENENT-2 (Німеччина). Еколого-ге- охімічну оцінку поверхневих відкладів за сумарним показником забруднення здійснено за методикою Ю. Ю. Саєта (Saet, 1990).

Завдяки значному поширенню на території України в умовах міських агломерацій трав'янистої рослини пирій повзучий (Elytrigia repens) було проведено еколого-геохімічне дослідження цього виду. Рослинні зразки являли собою усереднені проби укосів пирію повзучого, що росте на ділянках спостережень. Досліджували наземні частини рослин. Для характеристики біогенної міграції важких металів і біогеохімічних особливостей рослин застосовано методики розроблені Ю. Ю. Саєтом, Б. Б. Полиновим, О. І. Перельманом, І. А. Авессаломовою. Коефіцієнт біологічного поглинання (КБП) елемента розраховано за формулою (Avessalomova, 1987):

$$
\text { КБП }=\frac{L x}{N x},
$$

де $L x$ - вміст елемента в золі рослин, $N x$ - його вміст у грунті.

Для групування важких металів у рядах за інтенсивністю біологічного поглинання використано п’ять градацій (Avessalomova, 1987):

Елементи біологічного накопичення (КБП > 1):

І група - КБП - 10n і більше - елементи енергійного накопичення;

II група - КБП - $10-\mathrm{n}$ - елементи сильного накопичення.

Елементи біологічного захвату (КБП < 1):

III група - КБП - 0,n - елементи слабкого накопичення і середнього захвату;

IV група - КБП - 0,0n - елементи слабкого захвату;

V група - КБП - 0,00n і менше - елементи дуже слабкого захвату.

Для кількісного виразу загальної здатності виду до концентрації важких металів I. А. Авессаломова запропонувала спеціальний показник біогеохімічна активність (БХА) виду (Avessalomova, 1987), що являє собою сумарну величину, яка отримується від складання КБП окремих важких металів: БХА $=\sum К Б П$.

Таким чином, в основі розрахунку цього показника лежить загальний ефект накопичення важких металів у золі рослини, що складається 3 його часткових «активностей» відносно різних хімічних елементів.

Результати досліджень. У м. Маріуполь проведено дослідження чорноземів звичайних потужних малогумусних. Грунтотвірними породами на цій 
території є лесоподібні важкі суглинки та глини. У м. Алчевськ грунтовий покрив представлений чорноземами і дерновими грунтами на елювії безкарбонатних і карбонатних порід. Грунти м. Кам'янське представлені переважно чорноземами звичайними середньопотужними малогумусними на лесах. Грунти м. Шостка - дерново-середньопідзолистими легкосуглинистими на водно-льодовикових суглинках, підзолисто-дерновими легко суглинистими на озерних суглинках, дерново-середньопідзолистими глеюватими легко суглинистими на водно-льодовикових суглинках. Грунти м. Суми - чорноземами типовими мало- та слабогумусними на лесових породах, чорнозема- ми опідзоленими переважно на лесових породах, луговими солонцюватими на делювіальних і алювіальних відкладах. Грунти ділянок досліджень значною мірою піддаються техногенному впливу та можуть бути представлені урбано- та індустріземами.

Слід зазначити, що в геохімічній екології центральне місце посідає геохімічний фактор впливу (хімічні елементи та їх асоціаціi) (Ermakov, 2015). На основі даних щодо валового вмісту важких металів у грунтах санітарно-захисних зон промислових підприємств і регіональних фонових значень розраховано коефіцієнти концентрації та визначено геохімічні асоціації (табл. 1).

\section{Асоціації важких металів у грунтах санітарно-захисних зон промислових підприсмств}

Таблиия 1 (Karmazynenko, 2014; Kurajeva, 2016; Vojtjuk, 2015)

\begin{tabular}{|c|l|c|}
\hline № & \multicolumn{1}{|c|}{ Територія досліджень } & Асоціації важких металів \\
\hline 1 & ПАТ «Маріупольський металургійний комбінат імені Ілліча» & $\mathrm{Pb}_{41}>\mathrm{Cu}_{11,3}>\mathrm{Zn}_{6,4}>\mathrm{Cr}_{5,4}>\mathrm{Mn}_{5}$ \\
\hline 2 & ПАТ «Металургійний комбінат «Азовсталь» & $\mathrm{Cu}_{15,4}>\mathrm{Pb}_{10,2}>\mathrm{Zn}_{7,4}>\mathrm{Mn}_{4,2}>\mathrm{Cr}_{4}$ \\
\hline 3 & ПАТ «Металургійний комбінат «Азовсталь» & $\mathrm{Zn}_{8,3}>\mathrm{Pb}_{7,8} \geq \mathrm{Mn}_{7,8}>\mathrm{Sn}_{4}>\mathrm{Cu}_{3,5}$ \\
\hline 4 & ПАТ «Дніпровський металургійний комбінат імені Ф. Е. Дзержинського» & $\mathrm{Pb}_{9,9}>\mathrm{Zn}_{7,1}>\mathrm{Mn}_{6,3}>\mathrm{Cu}_{3}>\mathrm{Sn}_{2,5}$ \\
\hline 5 & ВАТ «АК «Свема» & $\mathrm{Cr}_{12,6}>\mathrm{Zn}_{6}>\mathrm{Cu}_{4,5}>\mathrm{Pb}_{2,8}>\mathrm{Ag}_{2,3}$ \\
\hline 6 & Завод «Зірка» & $\mathrm{Cu}_{5,4}>\mathrm{Zn}_{5,2}>\mathrm{Cr}_{4,5}>\mathrm{Pb}_{2,3}>\mathrm{V}_{1,6}>\mathrm{Ag}_{1,4}$ \\
\hline 7 & Шостківський завод хімічних реактивів & $\mathrm{Pb}_{33,8}>\mathrm{Zn}_{7,9}>\mathrm{Ni}_{6}>\mathrm{Cu}_{3}>\mathrm{V}_{2,6}>\mathrm{Ag}_{1,8}$ \\
\hline 8 & Золошлаконакопичувач ТОВ «Сумитеплоенерго» & $\mathrm{Cu}_{31}>\mathrm{Zn}_{4,2}>\mathrm{Pb}_{1,9}>\mathrm{Ni}_{1,5}>\mathrm{Cr}_{1,4}$ \\
\hline 9 & Основний корпус ТОВ «Сумитеплоенерго» & $\mathrm{Cr}_{6,6}>\mathrm{Pb}_{3,6}>\mathrm{Cu}_{2,8}>\mathrm{Ni}_{1,5}>\mathrm{V}_{2}$ \\
\hline
\end{tabular}

Примітка. Цифрові індекси біля символів елементів - коефіцієнти концентрації.

У визначених геохімічних асоціаціях для зон впливу підприємств чорної металургії найчастіше зустрічаються такі елементи: $\mathrm{Pb}, \mathrm{Zn}$, $\mathrm{Cu}, \mathrm{Mn}, \mathrm{Cr}$. Під час еколого-геохімічних досліджень у м. Шостка було відмічено, що в геохімічну асоціацію, на відміну від інших ділянок досліджень, входить Ag, валовий вміст якого у деяких місцях досягає 50 мг/кг, за фонового значення 0,03 мг/кг. Картування території м. Шостка показало приуроченість аномальних значень Ag до BAT «Акціонерна компанія «Свема»» та Шостківського казенного заводу «Зірка». Щодо ділянок зони впливу ТОВ «Сумитеплоенерго», виявилося, що грунти, що лежать у безпосередній близькості від золошлаконакопичувача, забруднені такими важкими металами: $\mathrm{Cu}, \mathrm{Zn}$, $\mathrm{Pb}, \mathrm{Ni}, \mathrm{Cr}$. Причому, у деяких точках значення $\mathrm{Cu}$ досягають 4000 мг/кг, за фонового значення 30 мг/кг. Установлено, що грунти зони впливу основного корпусу ТОВ «Сумитеплоенерго» ха- рактеризуються такою асоціацією важких металів: $\mathrm{Cr}, \mathrm{Pb}, \mathrm{Cu}, \mathrm{Ni}, \mathrm{V}$.

Для оцінки рівнів забруднення автор розрахував сумарний показник забруднення грунтів для санітарно-захисних зон промислових підприємств різного профілю (табл. 2). Території досліджень характеризуються різним рівнем забруднення від середнього (помірно небезпечного) до високого (небезпечного).

Під час вивчення геохімічної екології рослин основну увагу зосереджено на характері акумулювання хімічних елементів, зв'язках у системі: грунтрослина, встановленні КБП, видовому різноманітті, морфологічних змінах рослин, питаннях резистентності рослин до хімічних сполук та токсикантів, а також на антагоністичних взаємодіях між макро- та мікроелементами (Rish, 2001; Ermakov, 2015). Аналіз КБП дозволив виявити деякі закономірності в біологічному поглинанні важких металів цією рослинністю із твердої фази грунту (табл. 3). 
Оцінка аерогенних осередків забруднення (Karmazynenko, 2014; Kurajeva, 2016; Vojtjuk, 2015)

\begin{tabular}{|c|l|c|c|}
\hline \multirow{2}{*}{ № } & \multicolumn{1}{|c|}{ Територія досліджень } & $\begin{array}{c}\text { Середнє значення } \\
\text { сумарного показника } \\
\text { забруднення }\end{array}$ & Рівень забруднення \\
\hline 1 & ПАТ «Маріупольський металургійний комбінат імені Ілліча» & 73 & Високий (небезпечний) \\
\hline 2 & ПАТ «Металургійний комбінат «Азовсталь» & 43 & Високий (небезпечний) \\
\hline 3 & ПАТ «Металургійний комбінат «Азовсталь» & 33 & Високий (небезпечний) \\
\hline 4 & $\begin{array}{l}\text { ПАТ «Дніпровський металургійний комбінат імені } \\
\text { Ф. Е. Дзержинського» }\end{array}$ & 28 & Середній (помірно небезпечний) \\
\hline 5 & ВАТ «АК «Свема» & 36 & Високий (небезпечний) \\
\hline 6 & Завод «Зірка» & 32 & Середній (помірно небезпечний) \\
\hline 7 & Шостківський завод хімічних реактивів & 49 & Високий (небезпечний) \\
\hline 8 & Золошлаконакопичувач ТОВ «Сумитеплоенерго» & 36 & Високий (небезпечний) \\
\hline 9 & Основний корпус ТОВ «Сумитеплоенерго» & 16 & Середній (помірно небезпечний) \\
\hline
\end{tabular}

Результати еколого-геохімічних досліджень показали, що до елементів сильного біологічного накопичення для дослідженого виду рослинності належать $\mathrm{Mo} \mathrm{i} \mathrm{Cu}$. Елементи слабкого накопичення і середнього захвату - Sn, Mn, Co, $\mathrm{Ni}, \mathrm{Zn}$ та $\mathrm{Pb}$. Елементи слабкого захвату - Cr i V. КБП Cu високий, тому що цей метал має здатність утворювати міцні комплекси з органічною речовиною грунту. Також високий КБП Мо, оскільки це елемент високої біофільності (Koval'skij, 1970). Слабко і дуже слабко більшість рослин захоплюють $\mathrm{V}$ i Cr, які малорухомі у грунтах. Очевидно, з цієї причини в процесі видоутворення у рослин не виробилась потреба у цих елементах (Avessalomova, 1987). БХА, що характеризує інтенсивність поглинання елементів рослинами, становить 5-10. Чим вищі значення цього показника, тим більшим техногенним навантаженням характеризується територія. Зольність становить 12,5 - 14,5 \%, це підвищене значення порівняно із зольністю трав'янистої рослинності Українського Полісся (Samchuk, 2006). Таким чином, пирій повзучий, що росте на грунтах різного типу, з різним рівнем полі- та моноелементного забруднення характеризується вибірковим накопиченням хімічних елементів. Виходячи 3 цього, інформація щодо КБП має велике значення для розроблення методик фіторемедіації, але менш ефективна для еколого-геохімічної оцінки.

Установлення залежностей між концентрацією металів у грунті та в рослинах проводилось на прикладі м. Маріуполь (рис.), тому що об'єкти довкілля саме цього міста характеризуються найвищими рівнями забруднення із досліджених ділянок. Бар'єрну здатність грунтів оцінювали для тих металів, забруднення якими підтвердили попередні дослідження (Karmazynenko, 2014).
Оцінювання якості рослин за впливу важких металів тісно пов'язане 3 оцінюванням фізіолого-генетичних механізмів їх стійкості до важких металів. Відносна стійкість рослин до накопичення металів може бути продемонстрована графіком, побудованим у координатах: вміст металу в рослинах - вміст металу у грунті, що являє собою концентраційне поле точок та усереднювальну їх лінію. Чим більше відхиляється від тієї чи іншої осі на графіку тренд концентраційного поля (загин графіка), тим більшу бар'єрну спроможність відносно металу проявляє орган рослини. Наявність грунтового бар'єру передбачає послаблення токсичного впливу на рослини металу, присутнього у грунті. Важливо зазначити, що криві залежності вмісту елемента в рослинах від кількості в грунті показують тип акумуляції його рослинами. За індикаторного типу надходження елемента в рослини - безбар'єрне, воно прямо пропорційне вмісту елемента в грунті (Minkina, 2013).

Для трав'янистої рослинності району досліджень властивий різний тип акумуляції. Поглинання $\mathrm{Mn}, \mathrm{Cr}$ та V рослинами віднесено до індикаторного типу. Проведені еколого-геохімічні дослідження показали, що в умовах сильного техногенного навантаження бар'єрний тип накопичення характерний для $\mathrm{Cu}, \mathrm{Zn}$ та $\mathrm{Pb}$. Поглинання цих елементів віднесено до акумулятивного типу. Так, наприклад, за значення $\mathrm{Cu}$ у грунтах 30-50 мг/кг їі середній вміст у рослинах 187 мг/ кг, а у разі зростання значень $\mathrm{Cu}$ у грунтах до 200 300 мг/кг середній вміст їі у рослинах стає меншим - 156 мг/кг.

Висновки. На техногенно забруднених територіях за впливу підприємств різного профілю (чорної металургії, хімічної промисловості, енергетики) 
Таблиця 3

Середній вміст важких металів у грунтах та трав'янистій рослинності виду пирій повзучий (Elytrigia repens), відібраних поблизу промислових підприсмств

\begin{tabular}{|c|c|c|c|c|c|c|c|c|c|c|c|c|}
\hline \multirow{2}{*}{  } & \multirow[b]{2}{*}{ Показник } & \multicolumn{10}{|c|}{ Хімічний елемент } & \multirow[b]{2}{*}{ БХА } \\
\hline & & $\mathrm{Mn}$ & $\mathrm{Ni}$ & Co & $\mathrm{V}$ & $\mathrm{Cr}$ & Mo & $\mathrm{Cu}$ & $\mathrm{Pb}$ & $\mathrm{Zn}$ & $\mathrm{Sn}$ & \\
\hline \multirow{3}{*}{ 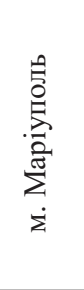 } & $\begin{array}{c}\text { Вміст у } \\
\text { рослинах, мг/кг } \\
(\mathrm{n}=250)\end{array}$ & 1440 & 37 & 4 & 7 & 15 & 18 & 200 & 56 & 179 & 6 & \multirow{3}{*}{9,66} \\
\hline & $\begin{array}{c}\text { Вміст у } \\
\text { грунтах, мг/кг } \\
(\mathrm{n}=250)\end{array}$ & 2297 & 81 & 10 & 163 & 238 & 3 & 267 & 461 & 539 & 7 & \\
\hline & КБП & 0,63 & 0,47 & 0,4 & 0,04 & 0,06 & 6 & 0,75 & 0,12 & 0,33 & 0,86 & \\
\hline \multirow{3}{*}{  } & $\begin{array}{c}\text { Вміст у } \\
\text { рослинах, мг/кг } \\
(\mathrm{n}=130)\end{array}$ & 1500 & 53 & 5 & 15 & 14 & 17 & 138 & 30 & 138 & 9 & \multirow{3}{*}{9,17} \\
\hline & $\begin{array}{c}\text { Вміст у } \\
\text { грунтах, мг/кг } \\
(\mathrm{n}=130) \\
\end{array}$ & 2515 & 59 & 6 & 150 & 140 & 5 & 73 & 101 & 460 & 12 & \\
\hline & КБП & 0,6 & 0,9 & 0,83 & 0,1 & 0,1 & 3,4 & 1,89 & 0,3 & 0,3 & 0,75 & \\
\hline \multirow{3}{*}{ 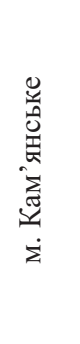 } & $\begin{array}{c}\text { Вміст у } \\
\text { рослинах, мг/кг } \\
(\mathrm{n}=150)\end{array}$ & 714 & 14 & 3 & 18 & 21 & 15 & 114 & 27 & 169 & 4 & \multirow{3}{*}{9,08} \\
\hline & $\begin{array}{c}\text { Вміст у } \\
\text { грунтах, мг/кг } \\
(\mathrm{n}=150)\end{array}$ & 1984 & 36 & 4 & 82 & 113 & 4 & 60 & 119 & 373 & 5 & \\
\hline & КБП & 0,4 & 0,39 & 0,75 & 0,22 & 0,19 & 3,75 & 1,9 & 0,23 & 0,45 & 0,8 & \\
\hline \multirow{3}{*}{ 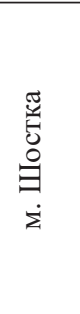 } & $\begin{array}{c}\text { Вміст у } \\
\text { рослинах, мг/кг } \\
(\mathrm{n}=230)\end{array}$ & 608 & 8 & 4 & 5 & 6 & 2,5 & 67 & 7 & 27 & 5 & \multirow{3}{*}{6,9} \\
\hline & $\begin{array}{c}\text { Вміст у } \\
\text { грунтах, мг/кг } \\
(\mathrm{n}=230)\end{array}$ & 943 & 78 & 20 & 31 & 30 & 1,5 & 21 & 43 & 132 & 13 & \\
\hline & КБП & 0,64 & 0,1 & 0,2 & 0,16 & 0,2 & 1,67 & 3,19 & 0,16 & 0,2 & 0,38 & \\
\hline \multirow{3}{*}{$\sum_{\dot{\Sigma}}^{\Xi}$} & $\begin{array}{c}\text { Вміст у } \\
\text { рослинах, мг/кг } \\
(\mathrm{n}=120)\end{array}$ & 442 & 9 & 2 & 8 & 10 & 6 & 432 & 20 & 60 & 3 & \multirow{3}{*}{5,01} \\
\hline & $\begin{array}{c}\text { Вміст у } \\
\text { грунтах, мг/кг } \\
(\mathrm{n}=120)\end{array}$ & 545 & 63 & 8 & 98 & 199 & 4 & 509 & 55 & 161 & 5 & \\
\hline & КБП & 0,81 & 0,14 & 0,25 & 0,08 & 0,05 & 1,5 & 0,85 & 0,36 & 0,37 & 0,6 & \\
\hline
\end{tabular}

Примітка. КБП - коефіцієнт біологічного поглинання, БХА - коефіцієнт біогеохімічної активності виду, $\mathrm{n}$ - кількість проб.

за показником накопичення в трав'янистій рослині пирій повзучий метали розміщуються в такий ряд: $\mathrm{Mo}>\mathrm{Cu}>\mathrm{Sn}>\mathrm{Mn}>\mathrm{Co}>\mathrm{Ni}>\mathrm{Zn}>$ $\mathrm{Pb}>\mathrm{Cr}>\mathrm{V}$.

За високого (небезпечного) рівня забруднення моніторингової площадки у м. Маріуполь встановлено наявність бар'єрних механізмів у системі грунт-рослина відносно $\mathrm{Cu}, \mathrm{Zn}$ та $\mathrm{Pb}$, дія таких бар'єрів щодо $\mathrm{Mn}, \mathrm{Cr}$ та $\mathrm{V}$ не проявлялась.

Аналіз концентраційних залежностей вмісту важких металів у системі грунт-рослина дає можливість використання рослин як біоіндикаторів забруднення довкілля важкими металами. Аналіз КБП дає менш чітку картину для еколого-геохімічної оцінки забруднення, тому що рослинність 

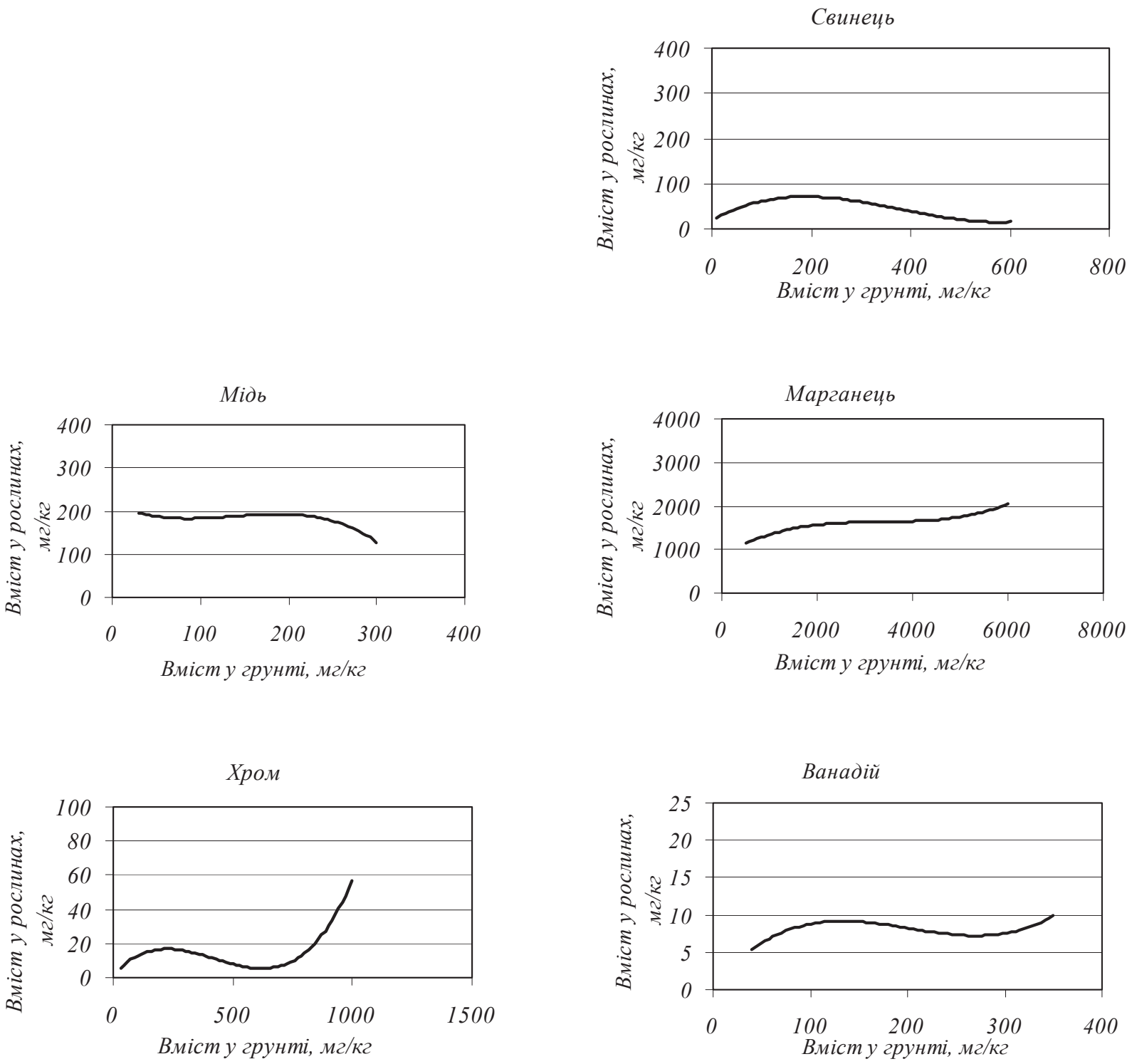

Рис. Концентраційні залежності вмісту важких металів у системі грунт-рослина

здатна вибірково накопичувати хімічні елементи. Така особливість рослинного покриву має велике значення для фіторемедіації.

\section{Бібліографічні посилання}

Koval'skij V.V., Andrianova G.A. 1970. Mikrojelementy $\mathrm{v}$ pochvah SSSR [Trace elements in soils of the USSR]. Nauka, Moscow (in Russian).

Samchuk A. I., Kurajeva I.V., Egorov O.S., Manichev V.J., Stadnyk V.O., Stroj A.M., Krasjuk O.P., Hudajkulova O.O., Ogar T.V., Bilyk V.V., Batijevs'kyj B.O. 2006. Vazhki metaly u g'runtah Ukrai'ns'kogo Polissja ta Kyi'vs'kogo megapolisu [Heavy metals in soils of Ukrainian Polissya and Kyiv megapolis]. Naukova Dumka, Kyiv (in Ukrainian).
Avessalomova I. A. 1987. Geohimicheskie pokazateli pri izuchenii landshaftov [Geochemical indicators in the study of landscapes]. Izd-vo MGU, Moscow (in Russian).

Minkina T.M., Motuzova G.V., Miroshnichenko N.N., Fateev A.I., Mandzhieva S.S., Chaplygin V.A. 2013. Nakoplenie i raspredelenie tjazhelyh metallov v rastenijah zony tehnogeneza [The accumulation and distribution of heavy metals in plants technogenesis zone]. Agrohimija, 9, 6575 (in Russian).

Ermakov V.V. 2015 Geohimicheskaja jekologija i biogeohimicheskie kriterii ocenki jekologicheskogo sostojanija taksonov biosfery [Geochemical ecology and biogeochemical criteria for evaluation of the ecological state of the biosphere taxons]. Geohimija, 3, 203-221 (in Russian) doi: $10.7868 / \mathrm{S} 0016752515030061$. 
Rish M.A. 2001. Genetic disorders of trace element metabolism in man and animals. Biogeochemistry and Geochemical Ecology. Moscow: NPC TMG MZ RF, 198-234.

Vojtjuk Ju. 2015. Tjazhelye metally v ob'ektah okruzhajushhej sredy pod vlijaniem teplojelektrocentrali g. Sumy [Heavy metals in the environment under the influence of heat and power plant in Sumy]. Modern science - Moderní věda. - Praha. -Ceská republika, Nemoros, 2, 146-152 (in Russian).

Kurajeva I.V., Kroi'k G.A., Vojtjuk Ju.Ju., Matvijenko O.V. 2016. Ocinka stupenju zabrudnennja urbanizovanyh terytorij [Assessment of pollution in urban areas]. Visn. Dnipropetr.Univ. Ser.
Geol. Geogr. 24 (1), 48-53 (in Ukrainian) doi: $10.15421 / 111608$.

Karmazynenko S.P., Kurajeva I.V., Samchuk A.I., Vojtjuk Ju.Ju., Manichev V.J. 2014. Vazhki metaly u komponentah navkolyshn'ogo seredovyshha m. Mariupol' (ekologo-geohimichni aspekty) [Heavy metals in the components of the environment. Mariupol (ecological and geochemical aspects)]. Interservis, Kyiv (in Ukrainian).

Saet Ju.E., Revich B.A., Janin E.P. 1990. Geohimija okruzhajushhej sredy [Environmental Geochemistry]. Nedra, Moscow (in Russian).

Надійшла до редколегії 5.09.2016 